UDC 005.94:004.9:331.103]-024.87

JEL Classification: M15; D83; J62; L86

\section{HEIDOR Alla,}

$\mathrm{PhD}$ (Economics),

Associate Professor at the Department

of Economics and Business Finance

of Kyiv National University

of Trade and Economics

Ukraine, 02156, Kyiv, 19, Kyoto str.

E-mail: a.heydor@knute.edu.ua

ORCID: 0000-0002-5098-0882
DOI: http://doi.org/10.31617/visnik.knute.2020(133)01

KASHPRUK Alona,

applicant for higher education with a master's degree from the Department of Digital Economy and System Analysis of Kyiv National University

of Trade and Economics Ukraine, 02156, Kyiv, 19, Kyoto str.

E-mail: elenakaschpruk@gmail.com ORCID: 0000-0002-7004-0513

\title{
IT ENTERPRISE KNOWLEDGE MANAGEMENT SYSTEM IN THE CONDITIONS OF REMOTE WORKFLOW
}

The article is dedicated to the basic principles of IT enterprise knowledge management system formation. Approaches to determining strategic structural components and factors which influence the successful functioning of the system are deepened and systematized. The generalized system of IT enterprise's intellectual potential management in the conditions of remote workflow is created.

Keywords: knowledge management, intellectual capital, knowledge management system, IT enterprise, remote workflow.

Гейдор А., Кашпрук А. Система управления знаниями IT-предприятия при дистанционном режиме работы. Исследованы основы формирования системы управления знаниями IT-предприятия. Систематизированы и углублены подходы к определению стратегических структурных компонентов и факторов влияния на успешное функиионирование этой системы. Создана комплексная система управления интеллектуальным потенциалом IT-предприятия в условиях дистанционного рабочего процесса.

Ключевые слова: управление знаниями, интеллектуальный капитал, система управления знаниями, IT-предприятие, дистанционный режим работы.

Background. The paper is dedicated to the principles of IT enterprise knowledge management system creation. The crucial significance of research is determined by the necessity to organize and maintain proper knowledge management strategy in remote work situations within IT companies. The system of remote work has been increasing dramatically in the last decade. According to Global Workplace Analytics, remote work has increased by $140 \%$ since 2007 among non-self-employed workers, and more than onethird $(37 \%)$ of knowledge workers now come into the office four or fewer times per week [1].

(C) Heidor A., Kashpruk A., 2020

ISSN 1727-9313. ВIСНИК КНТЕУ. 2020. № $5=5$ 
Among enterprises in different economic fields, the following tendency is clearly traceable in IT industry. Intellectual assets which contain enterprises employee knowledge, skills, trainings or any proprietary information that may provide the company with a competitive advantage should be organized properly. It is necessary to sustain productive functioning of a company, create value, and specify the firm's knowledge assets to meet company's organizational goals. A lot of companies face with obstacles of different kinds while adapting to remote work now. Therefore, it is necessary to create a mechanism of knowledge management system in IT enterprises in order to provide effective collaboration in remote working process through the set of initiatives, processes, strategies, and systems which support and enhance the creation, search, storage, and assessment, refinement, sharing, and applying of knowledge.

Thus, the aim of the work is to develop the generalized organizational management structure and knowledge management system (KMS) of the IT enterprises' intellectual potential based on the materials researched. As a result of the theoretical foundations research of the KMS and analyzing software products, the main components of the KMS were identified, the generalized systems of IT enterprise's intellectual potential management in the conditions of remote workflow on organizational and technical levels were created.

Analysis of recent researches and publications. The topic of the paper is quite new within scientific research, that is why the research of knowledge management (KM) aspects was performed in the works of not only scientists, but also experts in the knowledge management strategy: D. Andriessen, G. Roos, S. Pike, L. Fernstorm, C-H. Nilsson, D. Ford, D. Hislop, F. Omotayo,H. Harrington, F. Voehl, Z. Wahl.

The definition of the knowledge management systems seems vague considering the fact that there is no consensus regarding $\mathrm{KM}$ and what constitutes a KMS. Some scientists and experts regard KMS as technical aspect, while others include the organizational level also.

Intellectual capital and KM tools have been a focal point of discussion including both research and more practically oriented applications during the past decade. Professor of the School of Economics and Management in Sweden Carl-Henric Nilsson claims that it has emerged, 'in the light of a broader trend of redirecting the foundation of competitive advantage from the company's tangible assets to its intangibles such as knowledge base, brands and the content and the structure of computer-based systems' [2, p. 414].

Taking into consideration the essence of the category of "knowledge", it should be emphasized that it is an important strategic asset in the system of information engineering. Knowledge which is a compound of personal experience, values, contextualized, classified and calculated data (information), expert insight, and reasonable intuition can be distinguished in two different dimensions - tacit (that which is in people's heads) and explicit (coded) knowledge. KMS captures tacit and explicit knowledge in contrast to informational management systems. 
Furthermore, Donald Hislop, a professor in the sociology of work and technology in management (business school, University of Aberdeen, Scotland), defines tacit knowledge as 'embrained' knowledge, personal and context-specific knowledge of a person that resides in the human mind, behavior, and perception, evolves from people's interactions, highly personal (held within the holder), subjective, difficult to formalize, experience based, contextualized, job specific, transferred through conversation or narrative, not captured by formal education or training and even subconscious but capable of becoming explicit knowledge [3].

Explicit knowledge in contrast is formal and systematic; can be codified, collected, stored and disseminated, it is not bound to a person and has primarily the character of data $[4$, p. 6$]$.

Having studied various literary sources, it has been determined that $\mathrm{KM}$ is the systematic management of an enterprise's knowledge assets for the purpose of sustaining productive functioning of a company and creating value in order to meet tactical and strategic goals of a company.

Massachusetts Institute of Technology (MIT) paper states that the core goal of KM is to connect 'knowledge nodes' both the knowledge providers and the knowledge seekers to ultimately increase the knowledge within an organization [5].

Thus, within above mentioned goal, the main objectives of $\mathrm{KM}$ are the following: to capture and assess knowledge, to enhance and refine knowledge, to store and share knowledge, and to manage knowledge as an asset.

There are a number of approaches to KM. Thus, according to Wahl Z. group people approach KM in the following ways:

People-centric: centered on people, relationships, and how people form learning communities and other informal ways of knowledge sharing.

Tech-centric: focused on the technology that facilitates knowledge storage and transfer, and aims to create technology systems that encourage knowledge sharing.

Process-centric: interested in how the organizational structure and processes accommodate and encourage knowledge sharing and organizational learning. This concept includes the production processes, the organizational hierarchy, and the cultural framework [6].

We will generalize and combine all these approaches and components of $\mathrm{KM}$ in order to create complete KM system for IT enterprise.

According to the Buffer \& Angel List annual State of Remote Work survey $98 \%$ of respondents would like to work remotely, at least some of the time, for the rest of the career. At the top of the list of the biggest struggles with working remotely such aspect as "collaboration and communication" is observed [7].

The abovementioned aspect is a key problem, since the article focuses on remote workflow. That is why, to avoid all the challenges which arise from lack of interaction within the company, IT enterprises should resort to efficient KMS on both levels: organizational and technical. Employees need to be empowered to act more independently with remote 
work, but have timely access to the correct information. Efficient KMS ensures they can find actionable and accurate information. Thus, the article will focus on the KMS levels in more detail.

Materials and methods. Methods of analysis and synthesis have been used to study the theoretical foundations of knowledge management system formation. A system-structural approach has become the basis of applied aspects of the study, which allows to form the essence of the knowledge management system, as well as to distinguish its organizational and technical levels and components of each of them. Comparison methods are used to identify modern technical capabilities associated with the knowledge management system; formalizations for the development of an IT enterprise knowledge management platform; generalizations to formulate conclusions and prospects for further research.

Results. KMS exists on two levels: organizational and technical. Technical level serves as a technical component, as one of the elements of the generalized expanded KMS of organizational level. Thus, people-centric and process-centric approaches on organizational level and tech-centric on technical level are analyzed in order to create complete knowledge management system for IT enterprises in this article.

Knowledge Management System (Organizational Level).

On organizational level of KMS the expediency of creating a consolidated information infrastructure of an IT enterprise, in which a knowledge center that ensures an integrated information resource of the company will be the focal element, is observed. In this case, the type, complexity and hierarchy of organizational structure of intellectual potential management depend on a number of factors, including:

- the size, basic strategy and existing organizational structure of a company;

- the scale and diversity of intellectual resources (knowledge) of the enterprise;

- the structure of intellectual potential and its importance to achieve the commercial objectives of the enterprise; the level of specialization, concentration, combination and cooperation of production;

- the professional and qualification-educational level of personnel;

- product dynamism and differentiation, etc.

Analysis of scientific materials and experiences of business entities allow us to distinguish three main positions on the formation of this structure in the overall system of enterprise management: the use of the existing organizational structure of the enterprise, its expansion through the creation of a specialized unit, implementation of parallel independent structure.

In our case the most suitable approach is the improvement of the structure through the creation of a specialized unit (figure 1), which is responsible for managing the intellectual potential of the enterprise, as well as delegating part of the authority to the intellectual groups that are formed within the existing structural units. The leaders of the groups are the employees of the department of intellectual potential (knowledge) management. The main responsibility of the specialized structural units is to create the 
basic concept and goals of managing intellectual potential of the IT enterprise. Functional group leaders are responsible for overseeing the implementation of the strategy across within departments. At the same time, the immediate fulfillment of the tasks proceeds at the level of intellectual groups.

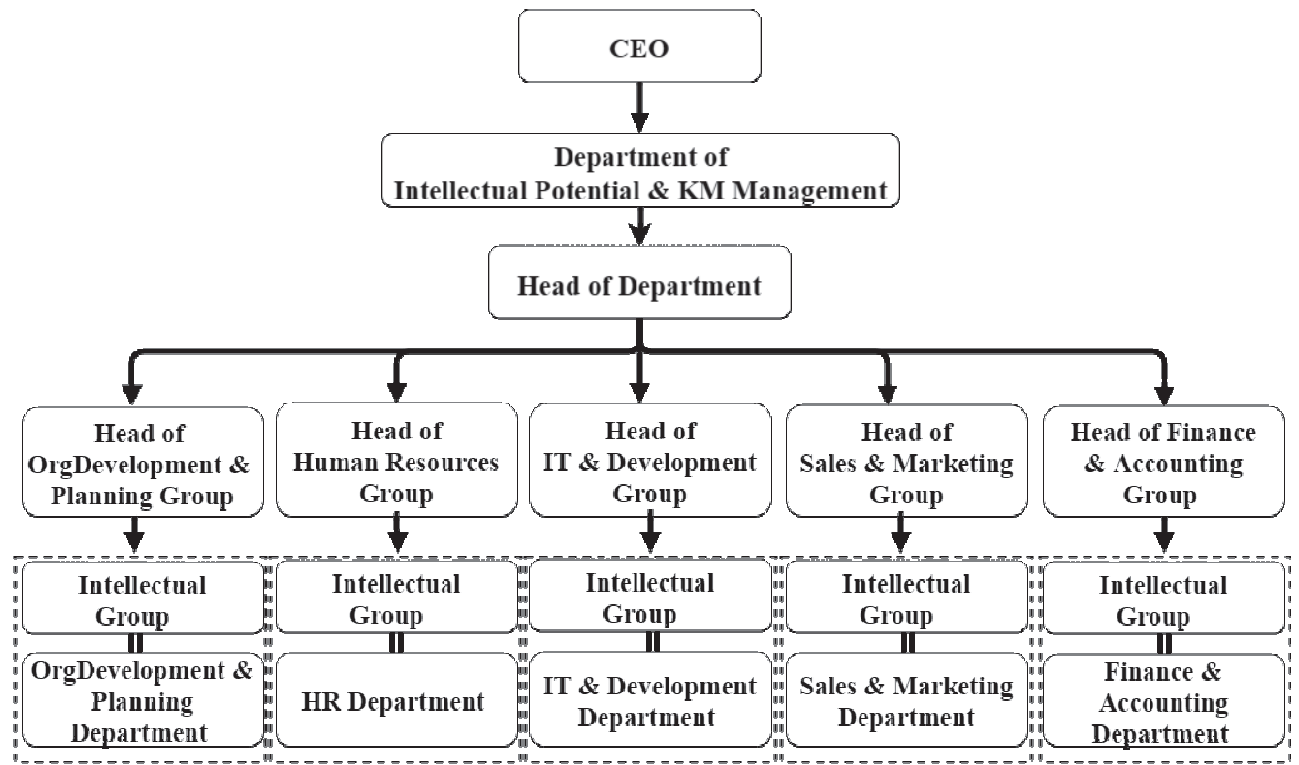

\section{Figure 1. Generalized Organizational Structure of Intellectual Potential Management of IT Enterprise in Conditions of Remote Workflow}

Source: developed by the authors.

Using of this approach ensures centralized knowledge management, timely data collection at a functional level and its further analysis at a centralized level. In addition, the effective cooperation of specialists in the field of knowledge management (head of department, team leaders) and qualified direct executives, who are well aware in the specifics of work of a certain department (intellectual groups), allows to achieve the goals set in the enterprise.

$\mathrm{KM}$ is a multidimensional phenomenon which consists of different aspects. After conducting a research of existing KMS on organizational level, its five main components which are the most crucial for IT enterprise's potential in the conditions of remote workflow are defined (figure 2).

Traditional knowledge management system is often regarded as a technology that helps the creation, capture and transfer of knowledge. The following article is based on the opinion illuminated by Helpjuice Company that KMS refer to any kind of IT system that stores and retrieves knowledge, improves collaboration, locates knowledge sources, mines repositories for hidden knowledge, captures and uses knowledge, or in some other way enhances the KM process. The definition of these systems seems vague considering the fact that there is no consensus regarding $\mathrm{KM}$ and what constitutes a knowledge management system. Furthermore, since KM is involved in all areas of the firm, strict definition is very difficult [8].

ISSN 1727-9313. ВIСНИК КНТЕУ. 2020. 


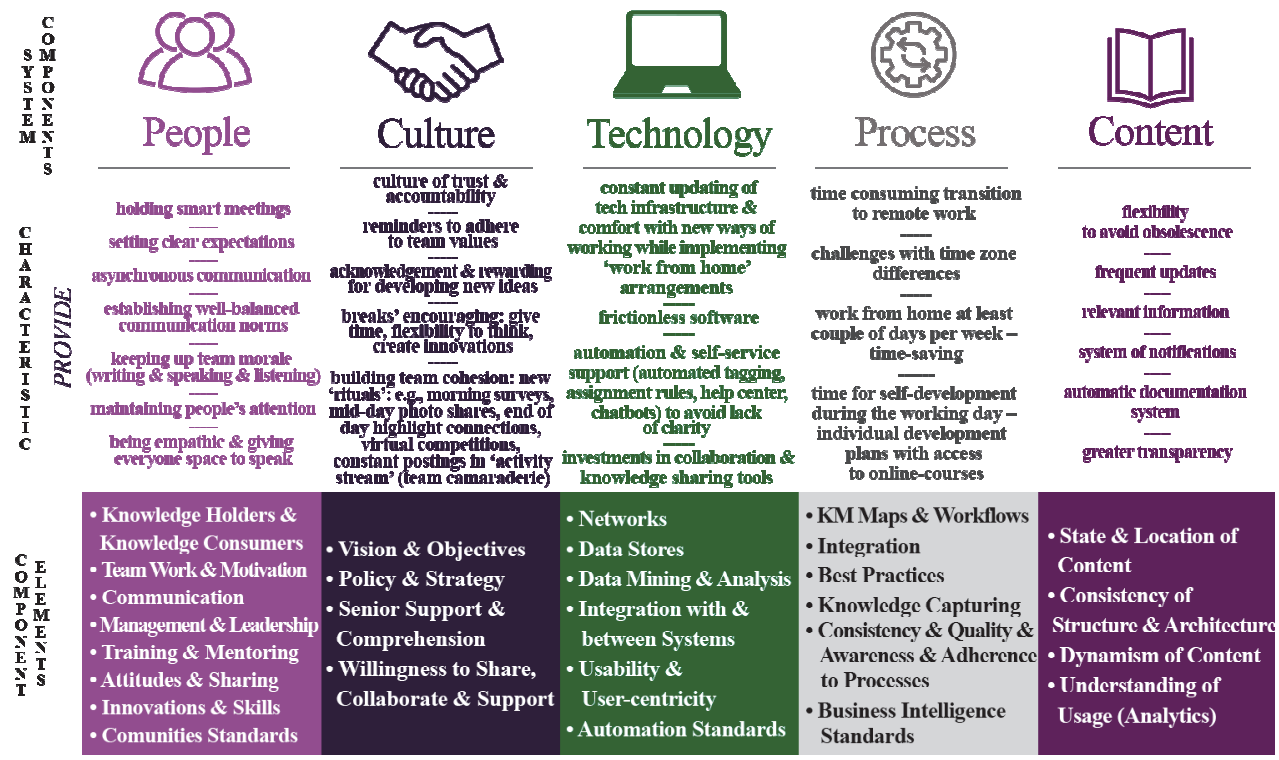

Figure 2. Components of IT Enterprise Knowledge Management System

Source: developed by the authors.

Knowledge Management System (Tech Level).

Besides, the mentioned company offers a scheme of KM lifecycle (figure 3) based on which knowledge management system is created.

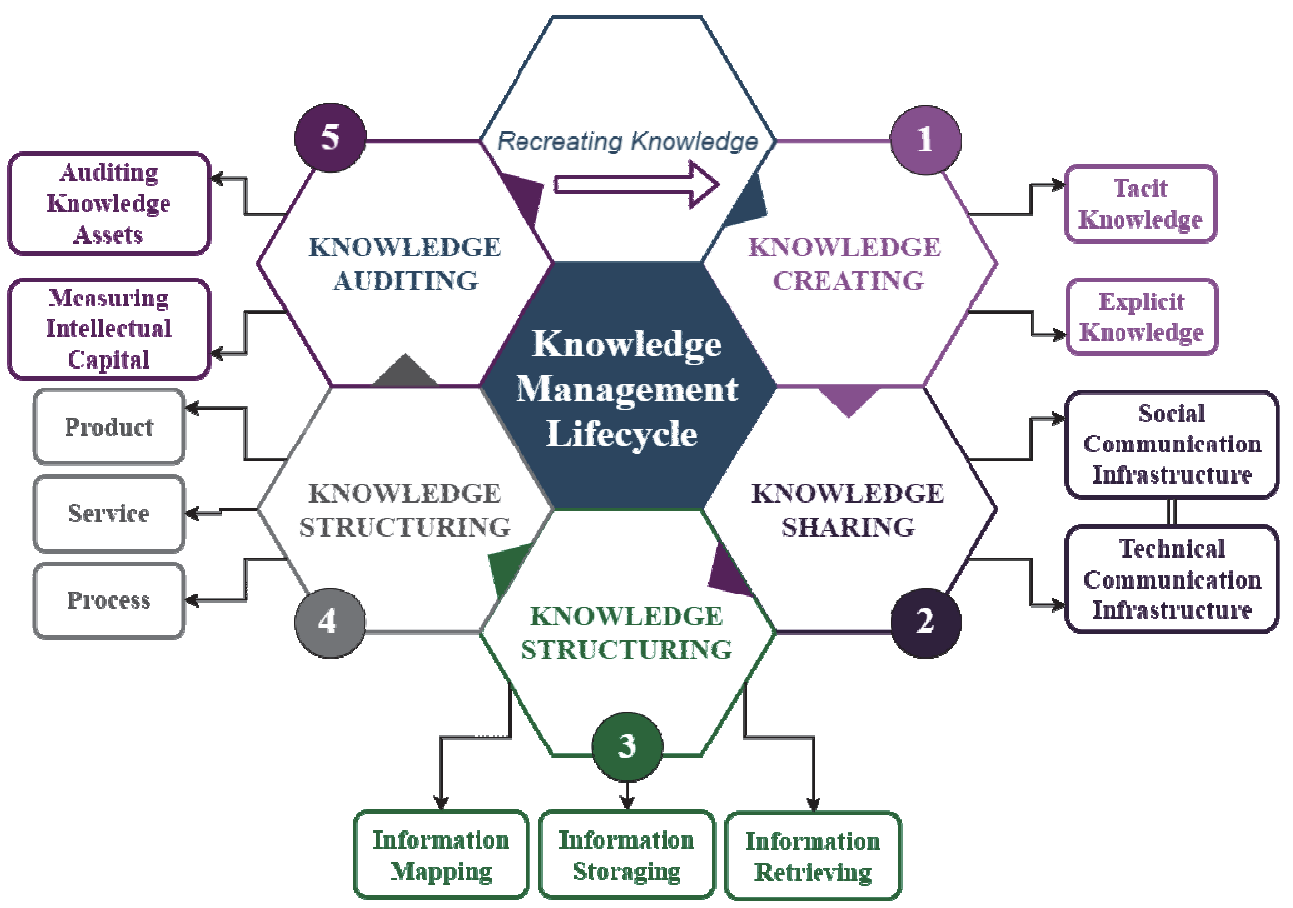

Figure 3. Knowledge Management Lifecycle

Sources: consolidated by the authors on the basis of [8]. 
Implementation of KMS in companies brings visible results. The study held by Teltech Resource Network Corporation (Teltech Group) among 93 enterprises revealed that the implementation of KMS was followed by: increasing profits (48\% of respondents), cost savings $(39 \%)$, improving customer service $(10 \%)$, and quality improvements $(6 \%)$, and processes improvements (4\%) [9, p. 187].

The development and effective use of quality software, which is well suited to the existing organizational structure and specificity of a particular IT enterprise, promotes the improvement of work in the company at all levels. Among the variety of modern technical capabilities, we have defined general categories of software tools that cover the vast majority of systems associated with KMS (table 1). Their combination has become the basis for the KM platform, the prototype of which has been created.

Table 1

Software tools (KMS)

\begin{tabular}{|c|c|}
\hline Type & Characteristic \\
\hline Groupware Systems & $\begin{array}{l}\text { Refers to any collaborative work platform that facilitates interactions between team } \\
\text { members and are usually intended for workers who need to communicate remotely } \\
\text { including a wide range of applications. There are synchronous groupware } \\
\text { (collaborate and update in real time, e.g., chat), asynchronous (e.g., e-mail) } \\
\text { groupware and community-focused tools(e.g., e-groups). Groupware systems } \\
\text { can be divided into three main groups: } \\
\text { communication tools: for sending messages and files, including email, publishing } \\
\text { on web, wikis, file sharing, etc. } \\
\text { conferencing tools: e.g. video/audio conferencing, chat, forums, etc. } \\
\text { collaborative management tools: tools for managing group activities, e.g. workflow } \\
\text { systems, project \& information management systems etc. } \\
\text { Examples: O365 / Teams, Slack, ShareFile, Firmex, Yammer, Microsoft Exchange, } \\
\text { Lotus Notes }\end{array}$ \\
\hline $\begin{array}{l}\text { Electronic Document } \\
\& \text { Content (Records) } \\
\text { Management Systems }\end{array}$ & $\begin{array}{l}\text { Performs versioning, storing and sharing documents; designed to manage, secure } \\
\text { and control documents across an enterprise; repositories of important corporate } \\
\text { documents. Codifying knowledge almost always results in documentation } \\
\text { (or another form of created content). Content Management tools manage contents: } \\
\text { fax, e-mails, HTML forms, computer reports, paper, video, audio or spreadsheets. } \\
\text { Examples: Alfresco, Documentum, Box.com, OpenText, GoFileRoom, } \\
\text { O365/SharePoint, Excalibur RetrievalWare, File Net }\end{array}$ \\
\hline $\begin{array}{l}\text { Data Warehousing } \\
\text { Data \& Data Mining \& } \\
\text { OLAP }\end{array}$ & $\begin{array}{l}\text { Process for collecting and managing data from varied sources to provide meaningful } \\
\text { business insights, typically used to connect and analyze business data from } \\
\text { heterogeneous sources for data analysis and reporting }\end{array}$ \\
\hline $\begin{array}{c}\text { Innovation Support } \\
\text { Tools }\end{array}$ & $\begin{array}{l}\text { Tools which contribute to knowledge creation through the product design process } \\
\text { and may consist various features: } \\
\text { tech databases with the recordings of patents, articles and research projects; } \\
\text { simulation tools used for modeling a real-world scenario and for testing insecure } \\
\text { or not economical to perform with the real-world equivalents' functions; } \\
\text { combinatory tools which aim is to support unusual opportunities in innovation } \\
\text { design or other creativity processes. } \\
\text { Example: Tech Optimizer }\end{array}$ \\
\hline $\begin{array}{c}\text { Intranet (Portals) \& } \\
\text { Extranet }\end{array}$ & $\begin{array}{l}\text { An intranet serves as a private secured network where employees can create content, } \\
\text { communicate, collaborate, and develop the company culture, operated by a large } \\
\text { enterprise which uses internet technologies, but is detached from the global internet. } \\
\text { An extranet serves as an intranet that can be accessible to figures from outside the } \\
\text { enterprise (partners, suppliers etc.), or shared by more than one company; it is often } \\
\text { used as a supplementary system which provides a shared network with limited, } \\
\text { controlled access to organizational information and knowledge resources, and using } \\
\text { security protocols (authentication) to limit access. } \\
\text { Example: Microsoft Internet Information Server }\end{array}$ \\
\hline
\end{tabular}


End of the table 1

\begin{tabular}{|c|l|}
\hline Type & \multicolumn{1}{c|}{ Characteristic } \\
\hline $\begin{array}{c}\text { Decision Support } \\
\text { Systems }\end{array}$ & $\begin{array}{l}\text { The main objective is support decision-making and solves problems by collaborating } \\
\text { with the manager rather than replacing him through the means of accessing and } \\
\text { manipulating data often by operating with data warehouse, online analytical } \\
\text { processing system (OLAP), data mining techniques. Presents information } \\
\text { to user in a manner that they can make informed decisions more easily }\end{array}$ \\
\hline $\begin{array}{c}\text { Knowledge Map } \\
\text { Systems }\end{array}$ & $\begin{array}{l}\text { Profile of competencies of the members of an organization that contain a 'who } \\
\text { knows what' list, without storing knowledge. } \\
\text { Examples: Lotus Discovery Server, Trivium Gingo }\end{array}$ \\
\hline $\begin{array}{c}\text { Competitive } \\
\text { Intelligence Tools }\end{array}$ & $\begin{array}{l}\text { Constant feeding the company's decision-making process with information about } \\
\text { the enterprise's environment with the further aim to make possible to learn about } \\
\text { it and to take better decisions. } \\
\text { Examples: VigiPro, Knowledge Works }\end{array}$ \\
\hline $\begin{array}{c}\text { Knowledge Databases } \\
\text { Technologies aimed at complex structured and unstructured information storage } \\
\text { used by a computer system. A database is a computer app which helps to capture, } \\
\text { store, analyze, and interact with data. } \\
\text { Examples: Zoominfo, Verve, Wealthbar, Boldbrush, InspectionXpert, Nexcess }\end{array}$ \\
\hline $\begin{array}{l}\text { Expecord tacit knowledge from a limited domain of human expertise and convert that } \\
\text { knowledge into the rules }\end{array}$ \\
\hline $\begin{array}{c}\text { Skill/Competency } \\
\text { \&Lessons Learned } \\
\text { Databases }\end{array}$ & $\begin{array}{l}\text { A knowledge repository system through which enterprise's staff capture, store } \\
\text { and manage intangible (tacit) knowledge from projects, events or operations making } \\
\text { it clear and available to other users }\end{array}$ \\
\hline $\begin{array}{c}\text { Artificial Intelligence } \\
\text { Tools }\end{array}$ & $\begin{array}{l}\text { Adopted into KM systems replaces the human consultants that had been analyzing } \\
\text { the data and monitoring the KM processes (cognitive computing, adaptive } \\
\text { technology, and intelligent filtering tools) }\end{array}$ \\
\hline
\end{tabular}

Sources: consolidated by the authors on the basis of $[8 ; 10 ; 11]$.

In the list of "100 Companies That Matter in Knowledge Management 2019" presented by KMWorld Magazine which spans a broad variety of companies that are each addressing the evolving demands of KM. Among a variety of enterprises such companies are mentioned: IBM, Google, Amazon Web Services, Oracle, EPAM, Adobe, Igloo Software, Quest, Wrike, Interfacing Technologies, Appian, MarkLogic, Microsoft, BloomReach, Dropbox, SAS, SmartSheet, GoodData, Xerox, Hyland etc. This list is an evidence of the fact that today's KM products and services (software) offered by leading companies put a high priority on getting the right knowledge to the right person at the right time keeping it safe from unauthorized access and including a bunch of new capabilities such as AI, machine learning, natural language processing, and digital assistants [12].

Based on the analysis of the abovementioned software tools in order to improve the KMS at the technical level, a prototype (represented by User Interface\&User Experience designs) of a platform for IT enterprises, aimed at remote work process for the company's team have been created (figure 4).

The key benefits of KM Platform usage are the following:

- creating new avenues for knowledge creation;

- providing easy collaboration and communication in remote work;

- keeping information up to date and easy to find;

- converting support emails to knowledge base articles;

- reducing wait times to get access to information needed;

- providing security and accountability. 


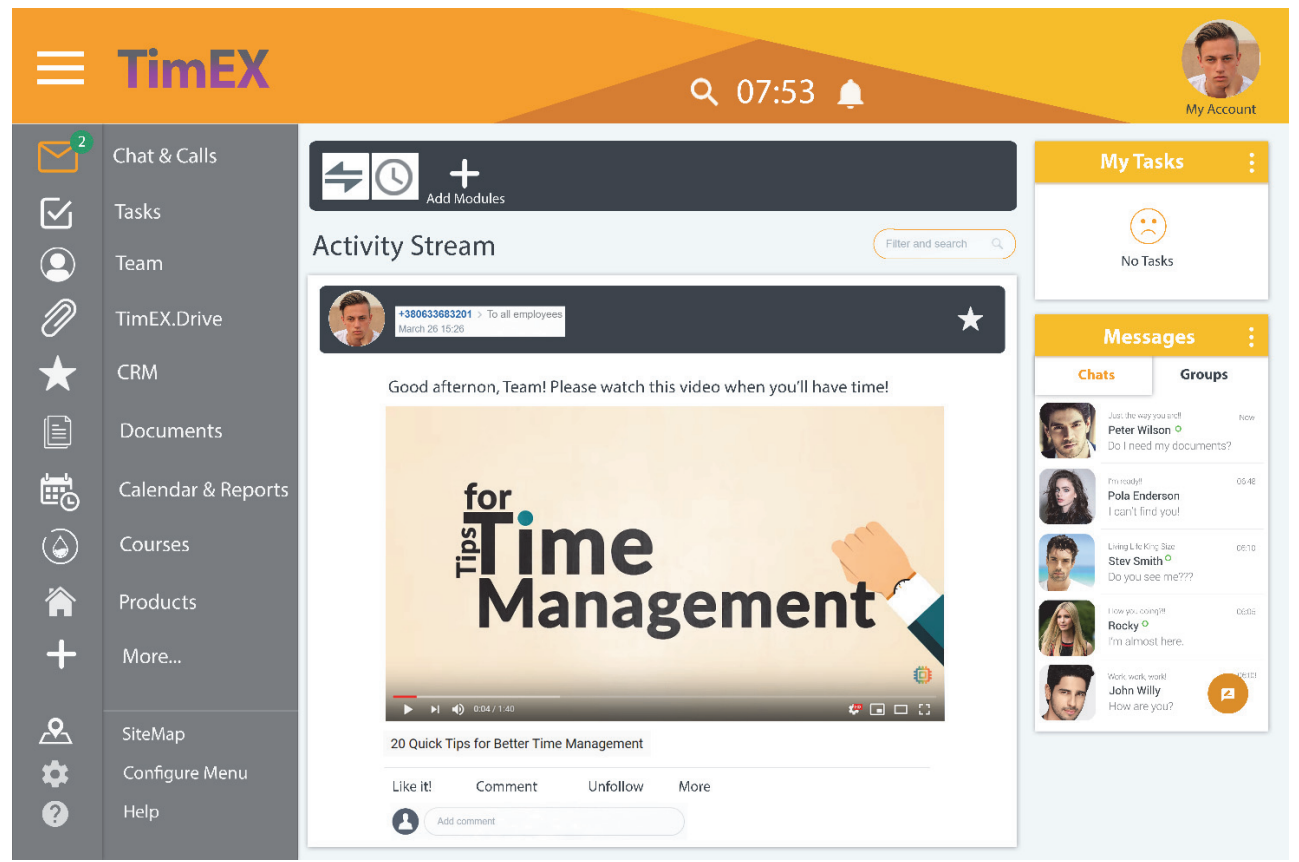

Figure 4. Knowledge Management Platform: Main Page

Source: developed by the authors.

The suggested KM Platform is a collaborative tool available for up to 30 team members including Android and iOS apps for efficient remote work process. The main features of the Platform are condensed and illustrated in (figure 5). mention:

Among other aspects of KM Platform, the following ones should be

- KM Platform provides multidimensional features for intranet and extranet services: different types of files support.

- It considers cloud PC integration or on-premise deployment (cloudhosted) and provides external communications management though extranet and CRM.

- KMS contains flexible educational component including academies and training programs, specialized learning courses, webinars and integration with education companies that offer a variety of video training courses (individual development plans for team members).

- The platform includes employee directory, task and work time reporting, absence tracking.

- It provides the possibility to carry out operations with documents including versioning of documents, and flexible permission systems.

- Collaboration and communications platform has tools for tasks tracking and coordination, time management and time planning (check-in/out feature, regular reports, events and meetings scheduler, and calendars).

It enables the access to forums/wiki/communities (including corporate blogs and company wiki). 


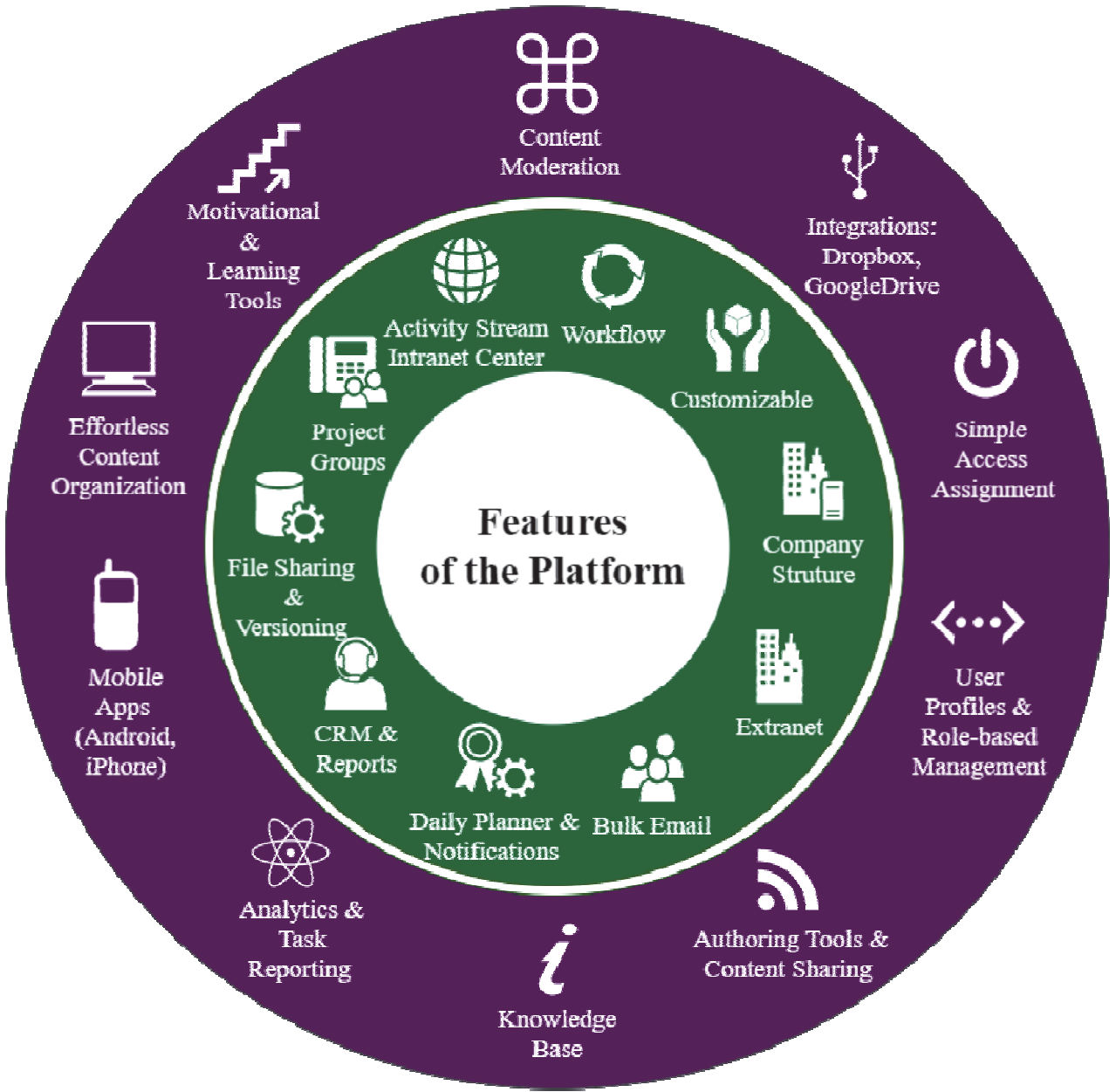

Figure 5. Features of KM Platform

Source: developed by the authors.

It is necessary to define a set of indicators that will allow us to evaluate the efficiency increase of business processes in an IT enterprise through the use of the offered knowledge management platform. Thus, a KPI (Key Performance Indicators) system (table 2) was formed.

Table 2

KPI system for evaluating the efficiency of the KM platform implementation

\begin{tabular}{|l|c|}
\hline \multicolumn{1}{|c|}{ Performance indicators } & Criteria for evaluating performance \\
\hline Time for work tasks performance by employees (h) & Decrease \\
\hline Communication difficulty level (\%) & \\
\cline { 1 - 1 } $\begin{array}{l}\text { The amount of tasks completed (the number } \\
\text { of operations) }\end{array}$ & \multirow{2}{*}{ Increase } \\
\cline { 1 - 1 } The level of task automation (\%) & \\
\hline The amount of overhead (monetary units) & \\
\hline Privacy level (\%) & \\
\hline
\end{tabular}

Source: developed by the authors. 
Thus, the developed platform can provide:

- reduction of time spent on fulfilling all necessary, mainly organizational, duties of the employee (including the time needed for communication within the team, getting access to knowledge, performing tasks, etc.), which will help to increase the level of effective interaction between employees within the company and between company, customers and partners;

- increasing the volume of completed tasks due to the increase in the speed of directly project activity performance of the IT enterprise;

- optimization of the roles of the employees involved, as the implemented software adopts certain functions and tasks that are usually included in the duties of workers (workload reduction, reduction of the number of indicators involved);

- timely transmission of information, rapid documentation preparation;

- reducing the cost of providing workers with "workplaces";

- increasing the security level within the company, which is guaranteed by the platform, while interacting with employees, documentation, etc.

The following platform is aimed at automation and standardization of knowledge management and provides help with security, data accuracy, and changes in technology (cost, implementation, usability). It is oriented on mediumsize IT enterprises with remote team work and may be customized to individual features of existing processes, workflows and culture of the company.

Conclusion. As a result of the theoretical foundations research of the knowledge management system and analyzing the rich variety of software products, the main components of the KMS have been identified and characterized, effective tools have been proposed, together with the organizational structure of intellectual potential management, a prototype of the knowledge management platform has been created. The effective IT company remote working process requires the implementation of the proper organizational system of intellectual potential realization and the knowledge management system on technical level. The knowledge management systems (both on organizational and technical levels) offered in this article can be improved and deepened to provide proper organizational management within a company. Further prospects in developing a mechanism for improving the quality of the enterprise's remote workflow are observed.

\section{REFERENCES}

1. Global Workplace Analytics report on remote work. Global work place analytics.com. Retrieved from https://globalworkplaceanalytics.com/telecommutingstatistics [in English].

2. Nilsson, C-H., \& Ford, D. (2004). Introducing intellectual potential. Journal of Intellectual Capital. (Vol. 5). 3, 414-425. Sweden. Retrieved from https://www.researchgate.net/publication/239920995_Introducing_intellectual_ potential_-_the_case_of_Alfa_Laval [in English]. 
3. Hislop, D. (2013). Knowledge management in organizations: A critical introduction. Oxford University Press 3rd Ed. UK. Retrieved from https://www.amazon.co.uk/ Knowledge-Management-Organizations-Critical-Introduction/dp/0199534977 [in English].

4. Omotayo, F. (2015). Knowledge Management as an important tool in Organisational Management: A Review of Literature. Library Philosophy and Practice. Retrieved from https://digitalcommons.unl.edu/cgi/viewcontent.cgi?article=3330 \& context=libphilprac [in English].

5. The Goals of Knowledge Management. Retrieved from http://web.mit.edu/ ecom/www/Project98/G4/Sections/section1b.html [in English].

6. Wahl, Z. (2020, March 4). KM Showcase: Conference View and Knowledge Management 2020 and Beyond. Retrieved from https://enterprise-knowledge.com/ km-showcase-conference-view-and-knowledge-management-2020-and-beyond [in English].

7. The 2020 State of Remote Work Survey. Buffer \& Angel List. Retrieved from https://lp.buffer.com/state-of-remote-work-2020 [in English].

8. Knowledge Management Tools (2018). www.knowledge-management-tools.net. Retrieved from http://www.knowledge-management-tools.net/knowledgemanagement-systems.html [in English].

9. Harrington, H., \& Voehl, F. (2007). Knowledge Management Excellence: The Art of Excelling in Knowledge Management. Paton Press. Retrieved from https://www.amazon.com/Knowledge-Management-Excellence-Art-Excelling/ dp/1932828117 [in English].

10. Carvalho, R., \& Ferreira, M. (2011). Using information technology to support knowledge conversion processes. Information Research. (Vol. 7), 1. Brazil. Retrieved from http://informationr.net/ir/7-1/paper118.html [in English].

11. Jatinder, N., Gupta, J., \& Sharma, S. (2015). Creating Knowledge Based Organizations. Idea Group Publishing. Hershey, PA, USA. Retrieved from https://www.slideshare.net/k_nitin_r/types-of-knowledge-management-systems [in English].

12. Wells, J. (2019). 100 Companies That Matter in Knowledge Management 2019. KMWorld. Journal. Retrieved from https://www.kmworld.com/Articles/Editorial/ Features/KMWorld-100-Companies-That-Matter-in-Knowledge-Management2019-129903.aspx [in English].

The article submitted to editor's office on 13.07.2020.

Гейдор А., Кашпрук А. Система управління знаннями IT-підприємства при дистанційному режимі роботи.

Постановка проблеми. Останнім десятиліттям в IT-індустріі чітко простежується тенденція до активного збільшення кількості віддалених робочих місиь. Під час адаптації до нового формату роботи вирішальне значення має створення механізму управління знаннями на IT-підприємствах для забезпечення ефективної співпраці в умовах віддаленого робочого процесу.

Аналіз останніх досліджень $\boldsymbol{i}$ публікацій засвідчив, щзо, попри глибокі дослідження та значні вдосконалення в галузі управління знаннями, існує нагальна потреба у створенні ефективної системи управління знаннями для IT-підприємств з подальшим впровадженням.

Мета статті - розкрити сутність понять "знання", "управління знаннями" та "система управління знаннями", визначити ключові складові системи управління знаннями, розробити узагальнену організачійну структуру управління та систему управління інтелектуальним потенціалом IT-підприсмства на основі досліджених матеріалів. 
Матеріали та методи. Теоретичне обтрунтування та прикладні аспекти дослідження базуються на таких загальнонаукових та спеціальних методах пізнання, як: узагальнення, формалізація, порівняльний аналіз, системно-структурний аналіз та синтез.

Результати дослідження. Проаналізовано сучасний стан системи управління знаннями на основі панівних тенденцій розвитку управління інтелектуальним потенціалом та підходів зарубіжних науковців. Для створення узагальненої системи управління знаннями проведено дослідження та систематизація підходів до визначення та формування управління знаннями, його складових та можливих труднощів y зв'язку з віддаленим робочим процесом IT-компаній. Питання системи управління знаннями досліджено в такій логічній послідовності: розкрито сутність понять "знання", "управління знаннями" та "системи управління знаннями"; визначено складові системи управління знаннями; виокремлено ефективні інструменти та практичні рекомендації щзодо його впровадження; розроблено узагальнену структуру управління та системи управління знаннями інтелектуального потенціалу IT-підприємств на основі досліджених матеріалів. Запропоновано узагальнену систему управління знаннями для IT-підприємств в умовах віддаленої роботи на двох рівнях: організаційному та технічному.

Висновки. У результаті дослідження теоретичних засад системи управління знаннями поглиблено та систематизовано підходи до визначення стратегічних структурних компонентів та факторів, які впливають на успішне функціонування системи управління знаннями. За підсумками аналізу різноманітних програмних продуктів запропоновано прототипи організаційної структури управління інтелектуальним потениіалом IT-підприємства та платформи системи управління знаннями.

Ключові слова: управління знаннями, інтелектуальний капітал, система управління знаннями, IT-підприємство, дистанційний режим роботи. 